\title{
Application of modified Michaelis - Menten equations for determination of enzyme inducing and inhibiting drugs
}

Saganuwan Alhaji Saganuwan(D)

\begin{abstract}
Background: Pharmacokinetics (PK) is the process of absorption, distribution, metabolism and elimination (ADME) of drugs. Some drugs undergo zero-order kinetics (ethyl alcohol), first order kinetics (piroxicam) and mixed order kinetics (ascorbic acid). Drugs that undergo Michaelis-Menten metabolism are characterized by either increased or decreased metabolism constant $(\mathrm{Km})$ and maximum velocity (Vmax) of enzyme reaction. Hence literatures were searched with a view to translating in vitro-in vivo enzyme kinetics to pharmacokinetic/pharmacodynamic parameters for determination of enzyme inducing and inhibiting drugs, in order to achieve optimal clinical efficacy and safety.

Methods: A narrative review of retrospective secondary data on drugs, their metabolites, Vmax and Km, generated in the laboratory and clinical environments was adopted, using inclusion and exclusion criteria. Key word search strategy was applied, to assess databases of published articles on enzyme inducing and inhibiting drugs, that obey Michaelis-Menten kinetics. In vitro and in vivo kinetic parameters, such as concentration of substrate, rate of endogenous substrate production, cellular metabolic rate, initial velocity of metabolism, intrinsic clearance, percent saturation and unsaturation of the enzyme substrate, were calculated using original and modified formulas. Years and numbers of searched publications, types of equations and their applications were recorded.
\end{abstract}

Results: A total of fifty-six formulas both established and modified were applied in the present study. Findings have shown that theophylline, voriconazole, phenytoin, thiopental, fluorouracil, thyamine and thymidine are enzyme inducers whereas, mibefradil, metronidazole, isoniazid and puromicin are enzyme inhibitors. They are metabolized and eliminated according to Michaelis-Menten principle. The order could be mixed but may change to zero or first order, depending on drug concentration, frequency and route of drug administration.

Conclusion: Hence, pharmacokinetic-pharmacodynamic translation can be optimally achieved by incorporating, newly modified Michaelis-Menten equations into pharmacokinetic formulas for clinical efficacy and safety of the enzyme inducing and inhibiting therapeutic agents used in laboratory and clinical settings.

Keywords: Enzymology, Drug, Michaelis-Menten equation, Pharmacokinetics, Efficacy, Toxicity 


\section{Background}

Elimination half-life, volume of distribution which is responsible for drug transport to sites of metabolism, maximum plasma concentration which could determine metabolism, enzyme saturation and elimination and maximum time (Tmax) reached, may be used to determine time of enzyme saturation, pharmacokinetic and pharmacodynamic response of drugs [1]. Cell organelles involved in metabolism and their dimensions are adiposomes $(20 \mathrm{~nm}-\mathrm{I} \mu \mathrm{m})$, amphisomes $(822 \pm 37 \mathrm{~nm})$, apicoplast $(0.15-1.5 \mu m)$, autophagosome $(0.15-1.5 \mu m)$, chloroplast (2-10 $\mu \mathrm{m})$, enlargesome, enosome (30-100 $\mathrm{nm})$, lysosome $(0.1-1.2 \mathrm{~nm})$, melanosome $(\simeq 500 \mathrm{~nm})$, mitochondria $(0.5-5 \mu \mathrm{m})$, nucleus $(\simeq 10 \mu \mathrm{m})$, peroxisome $(500 \mathrm{~nm})$, phagosome $(0.9-3 \mu \mathrm{m})$, secretory granule $(820 \pm 16 \mu \mathrm{m})$ and secretory synaptosome $(0.5-$ $3 \mu \mathrm{m})$. Hence analysis of organelle is vital for description of biochemical, molecular and physiological processes that are involved in pathogenesis of diseases, embryogeny, tissue differentiation, aging and treatment of various diseases [2]. Michaelis-Menten equation was used to estimate $\mathrm{Km}$ and $V \max$ from initial rate of reaction $\left(\mathrm{V}_{\mathrm{O}}\right)$, at substrate concentration $(\mathrm{Cs})$. However, it was assumed that the elimination rate of drug was partly a function of the drug concentration. Hence a minor change in the initial parameter may cause a large change in the final estimates [3]. Simple model incorporating Michaelis-Menten type elimination with one compartment model, using intravenous bolus had been published [4]. Nonlinear regression algorithms with numerical integration have been used to generate pharmacokinetic parameters. Administration of two or more doses yields better translation [3]. Hence preclinical pharmacokinetic studies remove some drugs out of discovery process [5]. Therefore the aim of the study is to integrate in vitro kinetics with in vivo kinetics with a view to optimizing clinical efficacy and safety of enzyme inducing and inhibiting drugs. As such the research question is, can Michaelis-Menten equation be modified for determination of liver enzyme inducing and inhibiting drugs and xenobiotics?

\section{Methods}

\section{Study design}

A narrative review of retrospective secondary data on drugs and their metabolites, Vmax and $\mathrm{Km}$, generated in the laboratory and clinical settings was adopted. The literature searched was carried out at Mannex Business Computer Centre, High Level Makurdi and at Crystalporttech Computer Centre Minna all in Nigeria between 1st July, 2019 and 30th June, 2020. Manuscripts published by Elsevier, Sage, Springer, Springer Nature, Tailor and Francis, Wiley among others were searched using Google Scholar, PubMed/Medline, Cochrane among others. The titles of the manuscripts were crosschecked with their contents and the fields of authors' research. A total of one hundred and twenty-one papers published between 1963 and 2020 were examined. Keywords search strategy was adopted, to access databases of the published articles, on drugs that obey MichaelisMenten principle (Table 1). Literature search entitled "pharmacokinetics of drugs that obey Michaclis-Menten principle of metabolism" was carried out with intent to identifying equations that could be used in identification of drugs that obey zero-order, first order and mixedorder kinetics. Keywords such as pharmacokinetic, metabolism, elimination, enzyme substrate, enzyme kinetic, inducer, inhibitor, metabolite, drug-combination, kinetic modeling, in vitro, in vivo among others were used to search for drugs that obey Michaelis-Menten principle. The inclusion criteria were, the papers published in English Languages, drugs whose metabolism constant $(\mathrm{Km})$ and maximum velocity (Vmax) have been reported, and the drugs that were either enzyme inducing or inhibiting, whose metabolic processes resulted in production of metabolites at specific doses, using different routes of administration. In vitro and in vivo equations have been included. The exclusion criteria were drugs that have no clinical application, and whose metabolic processes do not obey Michaelis-Menten principles. All articles published before 1963 on Michaelis-Menten principle have been excluded also. Maximum velocity of metabolism, metabolic rate constant, quantities of substrate and factors associated with metabolic processes of the drugs were also determined. Data generated from modified Michaclis-Menten equations (Table 2) were translated to kinetic parameters that were in turn guarded by metabolic processes of the drugs [6-51].

\section{Integration of in vitro-in vivo kinetic equations Michaelis-Menten and related equations}

Michaelis - Menten equations are given below

$$
\begin{aligned}
& \mathrm{V}_{0}=\mathrm{Vm} \times \mathrm{C} / \mathrm{Km}+\mathrm{C} \text { (Classic hyperbolic plot) } \\
& \frac{1}{k_{o}}=\frac{1}{\mathrm{~V}_{m}}+\left[\frac{k m}{0.632 \mathrm{~V}_{m}}\right] \frac{1}{\mathrm{C}_{o}}(\text { Modified Line-Weaver-Burk plot }) \quad(2) \\
& \text { Percent saturation }(\%)=\frac{100 \mathrm{C}}{\mathrm{km}+\mathrm{C}}
\end{aligned}
$$

Vo $=$ Initial velocity of reaction; Vmax $=$ Maximal velocity of reaction; $\mathrm{C}=$ Concentration of enzyme substrate; $\mathrm{Km}=$ Metabolism constant; $\mathrm{Ko}=$ Initial metabolism constant

Equations 1-3 can be used for determination of enzyme saturation during enzyme induction and inhibition process. 
Table 1 Types of searched articles, years of search and numbers of the articles sampled

\begin{tabular}{|c|c|c|c|c|}
\hline $\begin{array}{l}\text { Article } \\
\text { Type }\end{array}$ & $\begin{array}{l}\text { Year of } \\
\text { Publication }\end{array}$ & $\begin{array}{l}\text { Number of } \\
\text { Publication }\end{array}$ & Search Terms & Remarks \\
\hline Thesis & 2008 & 1 & Kinetic modelling & Integration of kinetic equations \\
\hline Chapter & $\begin{array}{l}2015 \text { and } \\
2019\end{array}$ & 2 & Kinetics and dynamics of antimicrobials & $\begin{array}{l}\text { Metronidazole, Isoniazid, Tylosin, } \\
\text { Mibefradil }\end{array}$ \\
\hline $\begin{array}{l}\text { Conference } \\
\text { Proceeding }\end{array}$ & 2009 & 1 & Drugs that obey Michaelis - Menten principle & Voriconazole \\
\hline Journals & $1963-2020$ & 112 & $\begin{array}{l}\text { Drugs that obey mixed, first and zero order kinetics; } \\
\text { metabolism; elimination; enzyme substrate; inhibitor; inducer; } \\
\text { metabolite; in vitro; in vivo }\end{array}$ & $\begin{array}{l}\text { Kinetic parameters of eleven enzymes; ( } 4 \text { ) } \\
\text { inhibiting and ( } 7 \text { ) inducing drugs were } \\
\text { obtained. }\end{array}$ \\
\hline Book & 1975-2015 & 5 & Enzymatic kinetics & Types of orders of kinetics obtained \\
\hline
\end{tabular}

Derived equations for calculation of non-linear drug kinetic parameters

Substitute clearance $(\mathrm{Cl})$ for $\mathrm{V}$ in the eq. 1 .

$$
\mathrm{Cl}=\frac{\mathrm{V}_{\max } \mathrm{C}}{k m+\mathrm{C}}
$$

Also substitute $\mathrm{V}$ for DR (dose rate) and $\mathrm{C}$ for Css (steady-state concentration in eq. (1).

$$
D R=\frac{\mathrm{V}_{\max } \mathrm{Css}}{k m+\mathrm{Css}}
$$

Also the modified Michaelis-Menten equation for consumed substrate that is endogenously produced is presented as

$$
V=\frac{\mathrm{V}_{\max } \times S}{k m+S}+R
$$

Where $\mathrm{R}$ is the rate of endogenous substrate production

$$
\text { Vo } \times \text { Clint }=\mathrm{R}
$$

$$
\text { Clearance }(C l)=D R / C_{S S}
$$

The eq. 5 and 7 are related.

Therefore

$$
D R=C l \times C s s
$$

Equate equations,4, 5 and 8

$$
\begin{aligned}
& D R=\frac{V_{\max } \times C_{S S}}{k m+C_{S S}}=C l \times C_{S S} \\
& C l=\frac{V_{\max } \times C_{S S}}{k m+C_{S S}} \times \frac{1}{C_{S S}}
\end{aligned}
$$

Hence

$$
\begin{aligned}
& \text { Css } \times \text { Clu }=\text { Urinary excretion } \\
& k_{o}=\text { Vmax }+ \text { urinary excretion }
\end{aligned}
$$

\begin{tabular}{|c|c|c|c|c|}
\hline Equation Types & $\begin{array}{l}\text { Number of } \\
\text { Equations }\end{array}$ & $\begin{array}{l}\text { Modified } \\
\text { Equations }\end{array}$ & Applications & Remarks \\
\hline Michaelis - Menten & 1 & 3 & Determination of enzyme saturation & Not perfect \\
\hline Non - linear kinetic & 17 & 17 & $\begin{array}{l}\text { Determination of rate - limiting and non - rate limiting } \\
\text { enzymes in mixed order kinetics }\end{array}$ & $\begin{array}{l}\text { Derived from Michaelis - Menten } \\
\text { equation }\end{array}$ \\
\hline Cellular metabolic rate & 5 & 3 & $\begin{array}{l}\text { Determines minimum and maximum level of } \\
\text { metabolism in cells }\end{array}$ & Obeys Eadie-Hofstee plot \\
\hline $\begin{array}{l}\text { Kinetics beyond } \\
\text { Michaelis - Menten }\end{array}$ & 11 & 6 & $\begin{array}{l}\text { Determination of drugs metabolized by allosteric } \\
\text { enzymes }\end{array}$ & Benzodiazepines as the examples \\
\hline $\begin{array}{l}\text { Non - linear mixed } \\
\text { kinetic }\end{array}$ & 15 & 10 & Determination of in vivo kinetics & $\begin{array}{l}\text { Simple method of determining } \\
\text { drug disposition }\end{array}$ \\
\hline $\begin{array}{l}\text { Narrow therapeutic } \\
\text { window }\end{array}$ & 2 & 0 & Determination of safe doses & It is good for renal impaired patient \\
\hline $\begin{array}{l}\text { Combined Michaelis - } \\
\text { Menten }\end{array}$ & 3 & 0 & Identification of liver enzyme inducers/inhibitors & $\begin{array}{l}\text { In vitro/In vivo integrated for } \\
\text { balanced kinetics/dynamics }\end{array}$ \\
\hline
\end{tabular}

At low rate of infusion when

$$
\begin{aligned}
& \text { Css }<<\mathrm{km}, \mathrm{K}_{\mathrm{o}}=C s s(C l u+V \max / \mathrm{Km}) \\
& \text { Loading dose }(\mathrm{LD})=C s s \times V d
\end{aligned}
$$

Table 2 Statistics of in vivo kinetic equations 
Enzyme inhibition constant $\left(k_{i}\right)=0.05 \times 1 C_{50}$

The maximal in vitro inhibitory concentration $\left(\mathrm{I}_{\max }\right)$ is the $C_{\text {max }}$ in human plasma

Therefore

invitro inhibitory potential $\left(\mathrm{I}_{P}\right)=\mathrm{I}_{\max } / k_{i}$

It translates to

invivo inhibitory potential $=\mathrm{C}_{\max } / \mathrm{ki}$

Whereas ki is the plasma inhibitory constant Equation (17) is identical with AUC ratio

Efflux ratio (Er) for drug moving across barrier $=\mathrm{Km} / \mathrm{Ki}$ or $\mathrm{Km} / \mathrm{IC}_{50}$

The carrier-mediated permeability $(\mathrm{Pm})$

$$
=\mathrm{Jmax} / \mathrm{Km}+\mathrm{Co}
$$

Clint = Intrinsic clearance; $\mathrm{S}=$ Substrate; Css- Steadystate concentration of drug;Clu-Urinary clearance; $\mathrm{Vd}=$ Volume of distribution; Inhibitory concentration 50; Jmax = Maximal carrier-mediated flux; Co = Initial donor concentration of the substance; $\mathrm{Km}=$ Metabolism constant [16]. At Css where metabolism is saturated, enzyme velocity approaches Vmax [49]. Therefore eqs. 420 can be used to determine rate-limiting and non-rate limiting enzymes that participate in zero order-first order kinetics (mixed order kinetics).

\section{Equations for calculation of drug metabolic rate in cell}

$$
\text { Metabolic rate }(M R)=a M^{3 / 4}
$$

$\mathrm{a}=$ Constant for all mammals; $\mathrm{M}=$ Body mass in $\mathrm{kg}$; metabolic rate is expressed in moles of oxygen consumed /second. But cell metabolic rate is:

$$
(\mathrm{CMR})=\frac{M R}{\text { Number of cells }}=a M^{-1 / 4}
$$

However, oxygen consumption rate per cell increases as body mass decreases.

$$
\begin{aligned}
& (\mathrm{CMR})=\frac{V_{\max }}{P}(\text { obeys Eadie-Hofstee plot }) \\
& \mathrm{P}=2.3026[52] . \\
& \text { but } \frac{d s}{d t}=\frac{-V_{\max } S}{k m+S}=-\mu(s) \\
& \text { Volume of drug }(V)=\frac{\text { Quantity of drug }}{\text { Concentration }}
\end{aligned}
$$

Equation 21 is referred to as specific growth function in cell growth modeling [53].

$$
V_{\max }(m g / h r) ; k m(m g / L)
$$

Equations 21-25 can be used to determine minimum and maximum level of drug metabolism in individual cells, which is a function of Eadie-Hofstee plot. At maximum velocity of enzyme reaction, the metabolism constant becomes negative. Hence removal of the drug from body system is invariably delayed.

\section{Kinetic equations beyond Michaelis-Menten order}

For reaction beyond Michaelis-Menten order, the following equation can be used. The equation describes the dependence of enzyme-catalyzed reaction on the concentration of substrate using catalytic constant $\left(K_{\text {cat }}\right)$ and Michaelis-Menten constant $(\mathrm{km})$. The $K_{\text {cat }}$ determines the maximum rate of the reaction at saturating substrate concentration $V_{\max }$.

Therefore

$$
V_{\max }=K_{c a t} \times E_{T}
$$

$1 \mathrm{~K}_{\mathrm{cat}}=60 \mathrm{~mol} / \mathrm{min}=6 \times 10^{7}$ units 11 unit $=1 \mu \mathrm{mol} /$ $\min =16.67$ nkat [54].

Where $E_{T}=$ the total enzyme concentration; $\mathrm{km}=$ the substrate concentration at which reaction is half of $V_{\max }$ [9].

$$
\begin{aligned}
& \text { Enzyme substrate }(E S)=\frac{\text { Kinfus }}{K_{c a t}} \\
& \begin{array}{l}
\text { When } S \ll k m \text { cleareance }(C l) \\
\quad=\frac{V_{\text {max }}}{k m} \text { (Linear Eadie-Hofstee plot) }
\end{array}
\end{aligned}
$$

Note that the enzyme will never reach its full activation.

When

$$
\mathrm{S}>>\mathrm{km} \text {, clearance }=V_{\max }[S]
$$

Note that the reaction is at full speed.

For acute dosing Clearance

$$
\begin{aligned}
& (C l)=\frac{V_{\text {max }}}{k m+S} \\
& \text { Rate }=C l X S=\frac{v m a x}{k m+s} X S \\
& E S_{S S}=\frac{\text { Kinfus }}{k_{\text {cat }}} \\
& A=\frac{v}{k}
\end{aligned}
$$

Where $\mathrm{A}$ is a lower boundary for concentration, $\mathrm{C}(\mathrm{t})$ Upper boundary for $\mathrm{C}(\mathrm{t})$ is 


$$
A=\frac{v}{k}+B
$$

$B=$ Maximum concentration $\mathrm{C}(\mathrm{t})$.

Replace $\frac{V}{K}$ by KE in the eqs. 33 and 34

Hence

$$
\begin{aligned}
& A=K E \\
& A=K E+B
\end{aligned}
$$

The standard kinetic parameters for intravenously administered drugs are Co (2.0), V (0.22) and $\mathrm{K}(0.11)$. Whereas KA (1.5), V (2.05), K (5.0), $\mathrm{D}_{1}$ (10.0), $\mathrm{D}_{2}$ (20.0) and $\mathrm{D}_{3}(40.0)$ have been reported for first order kinetics [3]. Equations 26-36 can be applied for determination of drugs that are metabolized by allosteric enzymes which have many active sites that are highly cooperative. The affinity of one active site can be affected by drug binding to another active site. Examples of such drugs are benzodiazepines (diazepam, lorazepam) that bind to ionotropic gama aminobutyric acid receptor. The drugs are either positive or negative Guanosine-protein coupled receptor. Hence they are nonconvalent.

\section{Non-compartmental/non-linear mixed kinetic equations}

$$
\begin{aligned}
& (C l)=V d \times \beta \\
& (C l)=\frac{V d}{M R T} \\
& V d \times \beta=\frac{V d}{M R T} \\
& M R T=\frac{V d \times \beta}{V d}=\beta \\
& A U C=\frac{D o s e}{C l} \\
& M R T=\frac{A U M C}{A U C}
\end{aligned}
$$

Equate eq. (40) with (42)

$$
\begin{aligned}
& M R T=\frac{A U M C}{A U C}=\beta \\
& \beta=\frac{A U M C}{A U C} \\
& C l=\frac{F(\text { Dose })}{A U C}
\end{aligned}
$$

Terminal half-life $\left(T \frac{1}{2} \beta\right)=\frac{V d}{P c l} \times 0.693$

Rate constant of elimination $(\mathrm{K} 10)=\frac{C l}{V c}$
$\mathrm{V}_{\mathrm{C}}=$ volume of central compartiment, $\mathrm{Vd}=$ volume of distribution; $T \frac{1}{2} \beta=$ elimination half-life, $\beta=$ elimination rate constant; $\mathrm{MRT}=$ mean residence time; $A U C=$ area under curve; $A U M C=$ area under moment curve.

Change in concentration over time is equal to dose of drug divided by apparent volume of distribution of the drug [55].

$$
\frac{d c(t)}{d t}=-\frac{\operatorname{Vmax} C(t)}{K m+C(t)}=C_{o}=\frac{D}{V_{a p p}}
$$

$\mathrm{Co}=$ Initial concentration; $\mathrm{D}=$ Dose of drug; Vapp = Apparent volume of distribution

$$
\begin{aligned}
& \text { Vss }=C l \times M R T=\frac{\text { Dose }_{i v} \times A U M C}{A U C} \\
& \text { Rate of metabolism }(\mathrm{Vo})=C l i n t \times C s \\
& \text { Clint }=V_{o} / C s=V \max / K m
\end{aligned}
$$

Clint $=$ proportionality constant between rate of metabolism and the drug substrate concentration at the enzyme site (Cs) [5]. Eqs. 37-51 can be used to calculate pharmacokinetic parameters of a drug concentration in vivo over a period of time. It is a linear, quick and simple method of evaluating drug disposition.

\section{Equations for adjusting serum concentration of enzyme inducing drugs}

Many enzyme inducing drugs for example phenytoin, have narrow therapeutic window phenomeno. Hence their serum concentrations can be calculated for patient with good renal function as follows:

$$
\begin{aligned}
& \text { Corrected Concentration } \\
& =\frac{\text { Observed Concentration }}{0.2 \times \text { Albumin }[\mathrm{g} / \mathrm{dL}]+0.1}
\end{aligned}
$$

The concentrations of enzyme inducing drugs for patients with end-stage renal failure are calculated thus:

$$
\begin{aligned}
& \text { Corrected Concentration } \\
& =\frac{\text { Observed Concentration }}{0.1 \times \text { Albumin }[\mathrm{g} / \mathrm{dL}]+0.1}
\end{aligned}
$$

Equations 52 and 53 can be used to adjust therapeutic dose of enzyme inducing drugs in patients with renal impairment or failure.

\section{Combination of plots of Michaelis-Menten equations}

Lineweaver-Burk double reciprocal equation is given as follows:

$$
\frac{1}{\mathrm{~V}_{\mathrm{o}}}=\frac{\mathrm{Km}}{\mathrm{V}_{\max }} \mathrm{x} \frac{1}{[\mathrm{~S}]}+\frac{1}{\mathrm{~V}_{\max }}
$$

Eadie-Hofstee plot is given as follows: 


$$
\mathrm{V}_{\mathrm{o}}=-\mathrm{Km} \times \frac{\mathrm{V}_{\max }}{[\mathrm{S}]}+\mathrm{V}_{\max }
$$

Hanes-Woolf plot is given as follows:

$$
\frac{[\mathrm{S}]}{\mathrm{V}_{\mathrm{o}}}=\frac{1}{\mathrm{~V}_{\max }}[\mathrm{S}]+\frac{\mathrm{Km}}{\mathrm{V}_{\max }}
$$

Note that eqs. 54-56 are modifications from Michaelis-Menten eq. I understand that none of the eq. $1-56$ is perfect. Hence the equations integrated herein can be for identification of liver enzyme inducing and inhibiting drugs.

Note that all the formulas 1-56 in the present context can be used in calculation of in vitro -in vivo pharmacokinetic, pharmacodynamic, and Michaelis-Menten parameters that can identify enzyme inducing and inhibiting drugs or toxicants.

\section{Statistical analysis}

Metabolic parameters were calculated quantitatively, whereas percent saturation was calculated qualitatively and the data generated were compared. The judgement of enzyme induction and inhibition was based on increased and decreased values of measured parameters. Also data generated were presented in average \pm standared error of mean (SEM). One-way analysis of variance (ANOVA) was used to analyze data, and honestly significant difference (HSD) was used to compare differences in variances at $5 \%$ level of significance [56].

\section{Results}

Kinetic integrated eqs. (1-56) presented above could be used for calculation of pharmacokinetic/pharmacodynamic parameters, to optimize clinical efficacy and safety of drugs. The equations could also be used for assessment of toxicokinetic/toxicodynamic parameters, for identification of potential hazards. Few parameters calculated using eqs. 1, 3, 6, 7, 21 and 49 are presented in Table 3. Values of kinetic parameters were significantly lower $(p<0.05)$ among inducers as compared to inhibitors (Tables $3 \& 4$ ). Enzyme inducers were theophylline, voriconazole, phenytoin, thiopental, thymidine, thymine, fluorouracil and tylosin. Enzyme inhibitors were mibefradil, metronidazole, isoniazid and puromycin. However, zero value of puromycin substrate concentration translated to zero rate of endogenous substrate production, initial velocity and $0 \%$ saturation. Rate of endogenous substrate production for metronidazole, phenytoin, thymidine and thymine was zero, in spite of available substrate, except for puromycin. Rate of endogenous substrate production and initial velocity of phenytoin that produced phenylhydantoin was zero, unlike phenytoin that produced hydroxyphenytoin, suggesting the later may be highly reactive. Nevertheless, the rate of endogenous substrate production of thiopental was negative, suggesting very low initial velocity of the metabolic process. In spite of zero level of rate of endogenous substrate production for thymine and thymidine, their substrate concentrations were yet high, suggesting lack of relationship between cellular metabolic rate and substrate concentration. Vmax, Cs, R, CMR, Vo, Clint, percent enzyme saturation and $\mathrm{S} / \mathrm{Km}$ were low among enzyme inducers whereas $\mathrm{Km}$ and percent enzyme unsaturation were much higher among inducers (Tables 3 \& 4).

\section{Discussion}

\section{Non-linear application of Michaelis-Menten equation}

Metabolic parameters of some drugs generated from Vmax and Km using Michaelis-Menten modified equations presented in Table 3, agree with the report indicating that nonlinear parameters, $\mathrm{Km}$ and Vmax obtained from steady state concentration measurements could be used to achieve optimal dosage regimen [58]. Simple intravenous, multi-dose bolus and constant injections can be described by lambert function, that fit the Michaelis-Menten parameters in designing dosing regimen, that maintains steady state plasma concentrations [55]. It is vital to maintain a concentration above minimum therapeutic level, all the times without exceeding the minimum toxic concentrations. Hence, onecompartment model with therapeutic window is relevant. Recently, one or two compartment models have been used to fit Michaelis-Menten parameters for single or multiple response data [3]. When fitting a model to Pk data for biologics with memberane bound targets, Michaelis-Menten is enough to describe the data, because only an upper bound for the receptor density can be identified [59]. If a metabolite is formed by Michaelis-Menten kinetics, linear plots of cumulative metabolite excreted in urine over time is not expected. The plasma clearance changes with dose of drug and it is expected to be different depending on dosage forms. Hence linear pharmacokinetic parameters could be evaluated using Michaelis-Menten equation [4] which states that a first order kinetics is observed at low substrate concentration, and the rate is independent of high substrate concentration [60].

\section{Enzyme- drug metabolite relationship}

During enzyme reaction, high metabolite is formed and the enzyme suddenly becomes saturated as the substrate concentration is increased. This is observed for theophylline, voriconazole, metronidazole, isoniazid and tylo$\sin$ (Tables $3 \& 4$ ). When metabolite is formed, rate of urinary excretion is equal to rate due to glomerular filtration plus rate due to active tubular secretion minus rate due to tubular re-absorption [4]. The calculated 


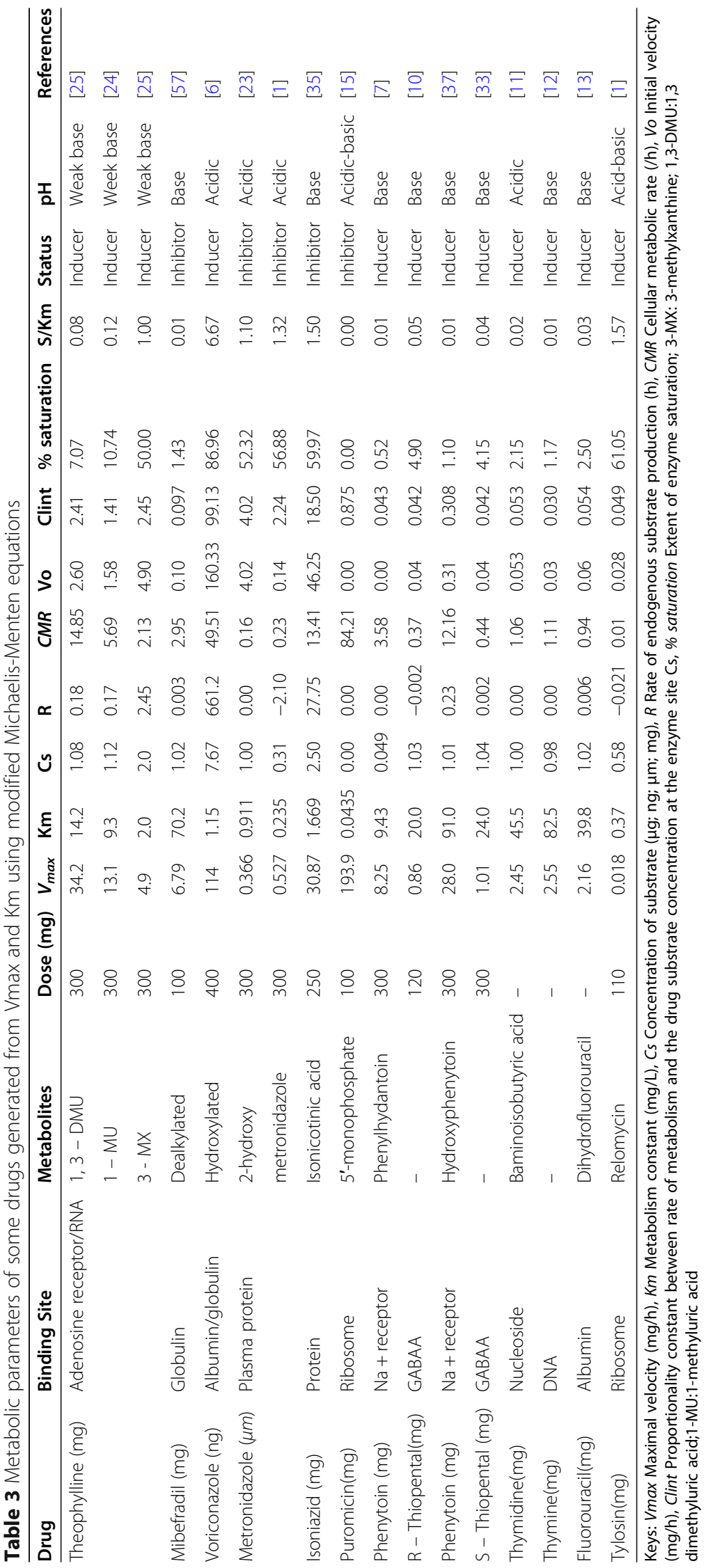


Table 4 Calculated comparative Michaelis - Menten parameters of some enzyme inducing and inhibiting drugs

\begin{tabular}{|c|c|c|c|c|c|c|c|c|c|c|}
\hline Drug & Vmax & $\mathrm{Km}$ & Cs & $\mathbf{R}$ & CMR & Vo & CLimt & $\begin{array}{l}\% \\
\text { Saturation }\end{array}$ & $\begin{array}{l}\% \\
\text { Unsaturation }\end{array}$ & $\mathrm{S} / \mathrm{Km}$ \\
\hline Theophylline* & $17.4 \pm 8.7$ & $8.5 \pm 3.5$ & $1.4 \pm 0.3$ & $0.9 \pm 0.8$ & $7.6 \pm 3.8$ & $3.0 \pm 1.0$ & $2.1 \pm 0.3$ & $22.6 \pm 0.6$ & $77.4 \pm 13.7$ & $0.4 \pm 0.3$ \\
\hline Mibefradil** & $6.8 \pm 0.0^{b}$ & $70.2 \pm 0.0^{\mathrm{a}}$ & $1.0 \pm 0.0^{b}$ & $0.0 \pm 0.0^{b}$ & $30.0 \pm 0.0^{b}$ & $0.0 \pm 0.0^{b}$ & $0.1 \pm 0.0^{b}$ & $1.4 \pm 0.0^{b}$ & $98.6 \pm 0.0^{a}$ & $0.01 \pm 0.0^{b}$ \\
\hline Voriconazile* & $114.0 \pm 0.0^{\mathrm{a}}$ & $1.2 \pm 0.0^{b}$ & $7.7 \pm 0.0^{\mathrm{a}}$ & $661.2 \pm 0.0^{\mathrm{a}}$ & $49.5 \pm 0.0^{a}$ & $160 \pm 0.0^{a}$ & $99.1 \pm 0.0^{a}$ & $87.0 \pm 0.0^{a}$ & $13.0 \pm 0.0^{b}$ & $6.7 \pm 0.0^{a}$ \\
\hline Metronidazole** & $0.45 \pm 0.1^{\mathrm{b}}$ & $0.6 \pm 0.3^{b}$ & $0.7 \pm 0.3^{b}$ & $-1.1 \pm 1.1^{\mathrm{b}}$ & $0.2 \pm 0.0^{b}$ & $2.1 \pm 1.9$ & $3.1 \pm 0.9^{a}$ & $54.6 \pm 2.3^{a}$ & $45.4 \pm 1.9^{b}$ & $1.2 \pm 0.1^{a}$ \\
\hline Isoniazid** & $30.9 \pm 0.0^{a}$ & $1.70 \pm 0.0^{b}$ & $2.5 \pm 0.0^{\mathrm{a}}$ & $27.8 \pm 0.0^{a}$ & $13.4 \pm 0.0^{\mathrm{a}}$ & $46.3 \pm 0.0^{a}$ & $18.5 \pm 0.0^{b}$ & $60.0 \pm 0.0^{a}$ & $40.0 \pm 0.0^{b}$ & $1.5 \pm 0.0^{\mathrm{a}}$ \\
\hline Puromicin** & $193.9 \pm 0.0^{\mathrm{a}}$ & $0.04 \pm 0.0^{b}$ & $0.0 \pm 0.0^{b}$ & $0.0 \pm 0.0^{b}$ & $84.2 \pm 0.0^{a}$ & $0.0 \pm 0.0^{b}$ & $0.9 \pm 0.0^{b}$ & $0.0 \pm 0.0^{b}$ & $100 \pm 0.0^{\mathrm{a}}$ & $0.0 \pm 0.0^{b}$ \\
\hline Phenytoin* & $18.1 \pm 9.9^{a}$ & $50.2 \pm 40.8^{a}$ & $0.5 \pm 0.5^{b}$ & $0.1 \pm 0.1^{b}$ & $7.9 \pm 4.3$ & $0.2 \pm 0.0^{b}$ & $0.2 \pm 0.1^{b}$ & $0.8 \pm 0.3^{b}$ & $99.2 \pm 0.3^{\mathrm{a}}$ & $0.01 \pm 0.0^{b}$ \\
\hline Thiopental* & $0.9 \pm 0.1^{b}$ & $22.0 \pm 2.0^{\mathrm{a}}$ & $1.0 \pm 0.0^{b}$ & $0.0 \pm 0.0^{b}$ & $0.4 \pm 0.0^{b}$ & $0.01 \pm 0.0^{b}$ & $0.04 \pm 0.0^{b}$ & $4.5 \pm 0.4^{b}$ & $95.5 \pm 0.4^{a}$ & $0.05 \pm 0.0^{b}$ \\
\hline Thymidine* & $2.5 \pm 0.0^{b}$ & $45.5 \pm 0.0^{\mathrm{a}}$ & $1.0 \pm 0.0^{b}$ & $0.0 \pm 0.0^{b}$ & $1.1 \pm 0.0^{b}$ & $0.1 \pm 0.0^{b}$ & $0.1 \pm 0.0^{b}$ & $2.1 \pm 0.0^{b}$ & $97.9 \pm 0.0^{\mathrm{a}}$ & $0.02 \pm 0.0^{b}$ \\
\hline Thymine* & $2.6 \pm 0.0^{b}$ & $82.5 \pm 0.0^{\mathrm{a}}$ & $1.0 \pm 0.0^{b}$ & $0.0 \pm 0.0^{b}$ & $1.1 \pm 0.0^{b}$ & $0.03 \pm 0.0^{b}$ & $0.03 \pm 0.0^{b}$ & $1.2 \pm 0.0^{b}$ & $98.8 \pm 0.0^{\mathrm{a}}$ & $0.01 \pm 0.0^{b}$ \\
\hline Fluorouracil* & $2.2 \pm 0.0^{b}$ & $39.8 \pm 0.0^{\mathrm{a}}$ & $1.0 \pm 0.0^{b}$ & $0.0 \pm 0.0^{b}$ & $0.9 \pm 0.0^{b}$ & $0.1 \pm 0.0^{b}$ & $0.1 \pm 0.0^{b}$ & $2.5 \pm 0.0^{b}$ & $97.5 \pm 0.0^{a}$ & $0.03 \pm 0.0^{b}$ \\
\hline Tylosin* & $0.02 \pm 0.0^{b}$ & $0.4 \pm 0.0^{b}$ & $0.6 \pm 0.0^{b}$ & $0.01 \pm 0.0^{b}$ & $0.01 \pm 0.0$ & $0.03 \pm 0.0$ & $0.05 \pm 0.0$ & $61.1 \pm 0.0$ & $39.0 \pm 0.0^{b}$ & $1.6 \pm 0.0^{a}$ \\
\hline
\end{tabular}

Keys: * Enzyme inducer; ** = Enzyme inhibitor; $\mathrm{a}=$ significantly higher $(P<0.05) ; \mathrm{b}=$ significantly lower $(p<0.05) ; \mathrm{Vmax}$ Maximal velocity $(\mathrm{mg} / \mathrm{h}), \mathrm{Km}$ Metabolism constant (mg/L), Cs Concentration of substrate $(\mu \mathrm{g} ; \mathrm{ng} ; \mu \mathrm{m} ; \mathrm{mg}), R$ Rate of endogenous substrate production $(\mathrm{h})$, CMR Cellular metabolic rate (/h), Vo Initial velocity $(\mathrm{mg} / \mathrm{h})$, Clint Proportionality constant between rate of metabolism and the drug substrate concentration at the enzyme site Cs, \% saturation Extent of enzyme saturation and unsaturation

$1.43 \%$ enzyme saturation of mibefradil is corroborated by the report, indicating that metabolites of mibefradil represent $50-80 \%$ of the circulating drugs after single oral drug administration. The metabolites are formed from cytochrome P450-mediated oxidation at saturation, dealkylation and hydrolysis of the ester side chain at unsaturation [61]. Mibefradil causes life-threatening interaction with beta blockers, digoxin, verapamil, and diltiazem with consequence of developing abnormal depolarization-repolarization of the heart ventricle (QT) prolongation [3]. However, a mibefradil metabolite is a potent blocker of L-type $\mathrm{C}^{2+}$ current in pancreatic beta cells, which is time-dependent and poorly reversible [57]. Metabolism of voriconazole via hydroxylation is faster than via $\mathrm{N}$-oxidation which are influenced by the cytochrome P450 (CYP) subfamily 2C19 genotype [39]. About $87 \%$ enzyme saturation of voriconazole in the present study connotes high level of metabolism and fast elimination. The finding is corroborated by the report indicating that voriconazole is absorbed in $2 \mathrm{~h}$ after oral administration, $90 \%$ bioavailable, with capacity-limited elimination, extensively distributed, $60 \%$ plasma protein bound and independent of plasma concentration. The elimination half-life is $6 \mathrm{~h}$ and $80 \%$ of the total dose is recovered in the urine as metabolite [42]. However, CYP2C19 and 219 genotypes are not major determinants of voriconazole metabolism [51] and $2 \%$ is excreted unchanged in urine [62]. However, metabolism of voriconazole could be autoaccelerated and controlled by cimetidine [30]. Metabolism of N-oxide voriconazole differs pre and post treatment [6].The terminal half-life is relevant to multiple dosing regimens as it controls degree of drug accumulation, concentration, fluctuations and time taken to reach equilibrium. When the process of absorption is a limiting factor, the terminal half-life reflects the extent of absorption and not the elimination process (Flip-Flop Mechanism) [63]. Isoniazid is converted to acetylisoniazid, isonicotinic acid, isonicotinylglycine, monoacetylhydrazine and diacetylhydrazine via acetylation. Fast acetylators acetylate isoniazid faster than slow acetylators 5-6 times more. Acid-labile hydrazones are also formed [64]. The formations of metabolite are via host activation of isoniazid and formation of isoniazid-NAD+ adduct [27]. Isonicotinic acid and isonicotinyl glycine are the only derivatives that contribute to isonicotinic fraction of isoniazid metabolites [35]. Therefore, toxic metabolites of isoniazid are increased in patients who are slow acetylators [65], and may account for about the $60 \%$ enzyme saturation reported in the present study. Acetyl isoniazid and diacetyl hydrazine could be determined after hydrolysis to isoniazid, acetyl hydrazine respectively [44]. Aminonucleose of puromycin is broken down to $5^{\prime}$-monophosphate of the nucleoside, seen 90 min after intravenous administration of puromycin [20], and could increase plasma free amino acid [15], perhaps accounting for $0 \%$ saturation. Phenytoin is metabolized to hydroxyphenytoin and phenylidantoin which has $\mathrm{S}$ and $\mathrm{R}$ isomers [43]. When the reaction is catalyzed by CYP2C9, formation of $\mathrm{S}$ isomer is favoured [7] as shown by low enzyme saturation, high Vmax and high $\mathrm{Km}$. However, 20-30\% difference between R- and S- isomer of thiopental clearance and Vss, could account for difference in their metabolic processes, [33] as observed by differences in their reported metabolic parameters in the present study. 
Non-linearity of drug kinetics depends on Vmax and km A low $\mathrm{Km}$ observed for theophylline $(2 \mathrm{mg} / \mathrm{L})$, voriconazole $(1.15 \mathrm{mg} / \mathrm{L})$, metronidazole $(0.235 \mathrm{mg} / \mathrm{L})$, isoniazid $(1.669 \mathrm{mg} / \mathrm{L})$, puromycin $(0.0345 \mathrm{mg} / \mathrm{L})$ and tylosin $(0.37 \mathrm{mg} / \mathrm{L})$ indicates high binding affinity as the reaction approaches Vmax rapidly. High $\mathrm{Km}$ observed for mibefradil $(70.2 \mathrm{mg} / \mathrm{L})$, thiopental $(20.0 \mathrm{mg} / \mathrm{L})$, theophylline $(14.2 \mathrm{mg} / \mathrm{L})$, phenytoin $(91.0 \mathrm{mg} / \mathrm{L})$, thymidine $(45.5 \mathrm{mg} / \mathrm{L})$, thymine (5-methyl uracil) $(82.5 \mathrm{mg} / \mathrm{L})$ and fluorouracil $(39.8 \mathrm{mg} / \mathrm{L})$ indicates inefficient binding of enzyme with substrate, hence $V_{\max }$ is reached when the substrate concentration is high enough to saturate the enzyme. However, $\mathrm{S} / \mathrm{Km}$ ratio of $0.01-1.6$ (Table 4) in the present study disagrees with the reported value of $0.01-1.0$. When $\mathrm{S}<<\mathrm{Km}$, the enzymatic rate is much less than Kcat, because most of the active sites are unoccupied. Therefore, when $\mathrm{S}$ is low, the concentration is almost negligible, resulting to $\mathrm{Km}>>\mathrm{S}$. $\mathrm{I}_{\max } / k_{i}$ Values of isoniazid were identical with the AUC ratio, whereas clofazimine showed high $\mathrm{I}_{\max } / k_{i}$ values by four folds. Hence drugs metabolized by CYP3A4 should be carefully administered with clofazimine [66]. Hence nonlinearity is observed in metabolism involving Michaelis-Menten kinetics called saturable metabolism or mixed order kinetics. Nonlinearity may be at different levels of absorption, distribution, metabolism and excretion [67]. The pharmacokinetics with absorption and elimination in the Laplace domain could be inverted. Right skew and maxima were seen in dimensionless concentration with time plot. The tendencies of individuals to show nonlinearity in theophylline kinetics depend partly on $\mathrm{km}$ and $V_{\max }$ values of their respective metabolic pathway and serum theophylline concentration [24]. Age and weight have been identified to affect pharmacokinetic variability of voriconazole [32]. Chemical and antibody inhibitors have no or little effect on metronidazole 2- hydroxylation, making CYP2A6 responsible for 2- hydroxylation of metronidazole both in vitro and in vivo [68]. The general disposition of a drug is the same of local disposition at various sites in the body, whereas the local disposition is the sum of micro-disposition in the cells. Therefore, understanding of the disposition in vitro and in loci is indispensable in clinical situations [69]. Botts- Morales theory on catalytic properties of an enzyme is related to allosteric effects [70]. Hence combination of either classic-hyperbolic Eadie-Hofstee or Line-Weaver-Burk double reciprocal-Eadie-Hofstee or Hanes-Woolf-EadieHofstee plot [71] may fit best for metabolism of enzyme inducing or inhibiting drugs. The negativity of $\mathrm{S} / \mathrm{Km}$ and $\mathrm{Km}$ of Eadie-Hofstee and Hanes-Woolf plots shows that, the reactants are being consumed on the reaction. However, before products are formed contrary to the classic hyperbolic plot that shows both reactants and products are present in the reaction.

\section{Enzyme-drug concentration determines the rate of reaction}

Subentical damped oscillations arise when Krebs cycle kinetics is obeyed. Such system could be considered as single compartmental pharmacokinetic model, where the drug concentration drops to zero over time, which is contrary to decaying exponentially with the axis as asymptote. A saw tooth pattern is seen in the concentration time plot for values of the frequency of oscillations, and ratio of the rate constants of infusion and excretion. Bimodal concentration curves cover frequencies of fluctuations [72]. Therefore, understanding of drugmetabolizing enzymes is a key to science of pharmacokinetics that may be used for treatment of drug abuse using enzymotherapy [73]. Zero rate of endogenous substrate production of thymidine and thymine in the present study, indicates that thymidine and thymine are extremely toxic. The finding agrees with the report indicating that, thymidine modulates a number of enzymes in deoxyribonucleic acid (DNA) synthesis or DNA apoptosis. Thymidine in combination with fluorouracil, a metabolite of capecitabine is very useful [40, 74], as a diminished thymidine pool is the mechanism underlying chemoprevention of colon cancer via alphadifluoromethylornithine [48]. Altered metabolism of thymidine could be caused by abnormal thymidine phosphorylase [41]. Deficiency of dihydropyrimidine dehydrogenase could lead to increased excretion of thymine, uracil, and 5-hydroxymethyl uracil. The affected persons usually become epileptic [46]. Metabolism of oral 5-fluorouracil differs from that of infused form, because the former undergoes more diverse metabolism in the liver and gastrointestinal tract using various enzymes [29]. The metabolites of 5-fluorouracil are dihydrofluorouracil and alpha-fluoro-beta ureidopropionic acid [19]. Dihydrofluorouracil could be detected in 5 min with metabolite of $23.7 \mu \mathrm{mol}$ in $60 \mathrm{~min}$ and half-life of $61.1 \mathrm{~min}$ [18]. Therefore, high $\mathrm{Km}(39.8 \mathrm{mg} / \mathrm{L})$, low enzyme saturation $(2.5 \%)$, and low rate of endogenous substrate production $(0.006 / \mathrm{s})$ in the present study, are suggestive of parenteral fuorouracil administration. Oral $110 \mathrm{mg}$ of tylosin yielded $40 \%$ potent metabolites, such as relomycin (tylosin D), desmycosin (tylosin B), dihydrodesmycosin, macrosin (tylosin C) and other 10 metabolites [21], accounting for $61 \%$ enzyme saturation and high receptor-binding capacity. Vmax and $\mathrm{Km}$ for linear least square using Eadie-Hofstee (193.9,0.0435), Hanes Woolf (216.2,0.0679), Line-Weaver-Burk (195.8; 0.0484), inverse Eadie-Hofstee $(215.8 ; 0.0670)$ and nonlinear least square $(212.7 ; 0.064)$ for puromicin shows that linear and nonlinear kinetics could fit into Michaelis-Menten order of kinetics [75]. However, the action of potential drugs is based on the inhibition/ activation of oxidoreductase [76]. The rate of ABC transport in NCF- 7 cells 
obeys Michaelis - Menten kinetics with $V_{\max }$ and $\mathrm{km}$ that show similar unimodal distributions, with different maximal cell populations. Higher $V_{\max } / \mathrm{km}$ ratio indicates higher efficiency of transport. Therefore, cell-cycle modulation of multidrug resistant should be taken into account when designing cytotoxic drugs [77]. Signifying that accurate and efficient estimation of enzyme kinetic parameters is beyond Michaelis-Merten equation [9].

\section{Drugs that obey Michaelis-Menten order of kinetics are liver enzymes inducers and inhibitors}

Thiopental and phenytoin are central nervous system depressants that, activate hepatic microsomal enzymes, whereas puromycin inhibits the enzymes. Activation is via oxidation of radicals at carbon $5, \mathrm{~N}$-dealkylation, destruction of barbituric ring and desulfuration of thiobarbiturates [78]. Thiopental increases liver weight, biliary flow and biliary excretion of glutathione conjugate [14]. Phenytoin activates cytochrome P450 and glucuronyl transferase enzymes, hence serum levels of steroids, lamotrigine, tiagabine, vitamin $\mathrm{K}$, cyclosporine, psycotropic, cardiovascular and antineoplastic agents act via CYPIA2, CYP2C9, CYP2C19, CYP3A4 and epoxide hydroxylase. Microsomal enzymes inhibitors, such as metronidazole, mibefradil and isoniazid modulate expression of pegylated - glycoprotein, and, multiple drug resistance proteins 2 and 3 in the gastrointestinal tract [79-81], with attendant consequences of higher cancer mortality, progression of acquired immune deficiency syndrome (AIDS), unwanted pregnancy and rejection of organ transplants. Time course of enzyme induction is governed by receptor up regulation and synthesis of new enzymes. Maximal induction of enzymes is faster with short half-life drugs versus drugs with long half-life. Hence the rate- limiting step is enzyme turn over [82], as could be seen in cases of co-administration of phenytoin with metronidazole. Furthermore, puromycin could be inhibited by chloramphenicol via ribosomes. However, enzymes induction by 3- methylcholanthrene and phenobarbital could be inhibited by puromycin [83]. Isoniazid $(30-50 \mu \mathrm{mol})$ inhibits activities of enzyme subfamily CYP2CI9 and CYP3A4 [84]. Either thymine or uracil could react with ribonucleosides or deoxyribonucleosides. The ratio of activity between oxyriboside transferring enzymes and deoxyriboside transferring enzyme is 3.5 and reduced to 0.06 in hepatoma [12], but 5flurouracil forms complex with thymidylate synthase, preventing DNA components of ribonucleic acid (RNA) and DNA [50] in cancer patients. Also 5-fluorouracil inhibits CYP4502C9 [17]. Voriconazole inhibits activities of CYP3A4 in microsomes of liver whereas, metronidazole inhibits CYP2C9 responsible for metabolism of $\mathrm{S}$ warfarin hydroxylation and constitutive androstane receptor that, regulates CYP2C9 and other CYP isozymes
[23]. Hence enzyme polymorphism may affect patients' response to co-administration of the drugs being studied. The most significant enzymes are CYP2D6 and CYP3A4 [85] but CYP3A4 and P-glycoprotein of 0.6 and $0.8 \mu \mathrm{mol}$ are respectively inhibited [47]. Adverse drug reaction of mibefradil is a reflection of CYP3A4 inhibition in liver and intestine [86]. Induction of hepatic cytochrome (P450) and microoxygenases suggest a mixed type induction by theophylline. Enzymes induction by phenytoin is compensated by increased dose of voriconazole [38]. Inducing and metabolising drugs adversely affect anaesthetics [87]. Liver enzymes cause hepatic hypertrophy [88]. However, substrate depletion and quantification of metabolites can be optimally for determination of kinetic parameters. A typical (non-Michaelis-Menten) occurs when two molecules of the same or different substrates simultaneously activate the active site. The kinetics is biphasic which could be sigmoidal (autoactivation), heteroactivation, substrate inhibition and partial inhibition [72].

\section{Drug-receptor binding affinity is a function of Michaelis- Menten kinetics}

The transport mechanism of $\mathrm{Na}^{+} / \mathrm{k}^{+}$- ATPase obeys ping-pong mechanism, whereby $\mathrm{Na}^{+}$binds to an allosteric non specific site leading to a 2 -fold increase in ATPase activity. Michaelis-Menten kinetics is obeyed, when the maximum exponent on the concentration of the varying reactant binds to only one enzyme reaction intermediate. But non-Michaelis-Menten kinetics occurs, when the varying reactant is both substrate and inhibitor (substrate inhibition) or participates in alternative productive pathways or when its stoichiometric coefficient is $>1$. Most enzymes follow Michaelis Menten kinetics [89]. Phenytoin- isoniazid interaction could be managed using pharmacokinetic method of Michaelis - Menten order with $V_{\max }$ in normal range and $\mathrm{Km}$ increased by five- fold [49]. Clofazimine and prothionamide may cause drug-drug interaction when co-adminstered with compounds metabolized by CYP 3A4 and CYP2B6, respectively. Whereas isoniazid and rifapentine may cause drug-drug interaction with drugs metabolized by CYP3A4 [67]. Enzyme efficiency is constrained by substrate concentration, genes, and ages, which allows systems modeling from the level of cellular chemical reactions to whole body physiological parameters [90]. For example, $\mathrm{Km}$ for carbonic anhydrase is 26 $\mathrm{mmol} / \mathrm{L}$ [91]. $V_{\max }$ and $\mathrm{km}$ estimation by linear methods provide, the most accurate and precise results [92]. Noncompartmental analysis is easier and does not require data modeling, and provides good results as nonlinear mixed effect model for analysis of bioequivalence data, AUC and $C_{\max }$ are estimated by non-compartmental analysis [93]. Mibefradil pharmacokinetics obeys 
Michaehs-Menten order of kinetics [22], which may be well approximated by a linear model for a single drug exposure, but more than one dose expose nonlineal system, that underestimates the uncertainty in the estimates [3].

\section{The fundamental pharmacokinetic parameters that could be integrated both in vitro and in vivo}

Clearance, volume of distribution, half-life and bioavailability are the fundamental pharmacokinetic parameters [94]. For albumin binding drugs, the effect of albumin on in vivo prediction from in vitro data is very vital for hepatic transporter substrates [95]. High degree of protein binding, narrow therapeutic window, high degree of protein binding drug example phenytoin, and non-linear pharmacokinetics complicate phenytoin dosing. At every high doses $\mathrm{R}$ - and $\mathrm{S}$ - thiopental exhibit a linear one compartment model with first order kinetics, and becomes nonlinear one-compartment model with Michaelis-Menten kinetic order. Fraction of unborn R thiopental used to be higher in this condition [10]. Pharmacokinetics of reversible metabolism, could predict appropriate doses of drug that is subjected to equilibrium in human body [13]. The relation between substrate concentration and dose rate reduces to a linear system [95]. Kinetic constants in the Michelis-Menten metabolism from one enzymatic assay could be approximated using Bayesian computation [96]. Also pharmacokinetics of thymidine, thymine, and fluorouracil is nonlinear in dose [11]. Therefore, terminal half-life is time required to divide plasma concentration $(\mathrm{Cp})$ by two after pseudo-equilibrium has been reached. If the absorption is not a limiting factor, half-life is a hybrid parameter controlled by plasma clearance and extent of distribution. If the absorption is a limiting factor, terminal half-life is a reflection of rate and extent of absorption not elimination [60]. Also lysine 69 is catalytic via $M$. tuberculosis shikimate dehydrogenase and should be used in rational design of antitubercular drugs [97], perhaps with isoniazid. The Hill coefficient of $2.05 \pm 0.1$ could suggest multiple substrates binding site [98]. Km $(1.15 \mu \mathrm{g} / \mathrm{ml})$ and $\operatorname{Vmax}(114 \mu \mathrm{g} / \mathrm{h})$ have been reported for voriconazole administered at $6 \mathrm{mg} / \mathrm{kg}$ every $12 \mathrm{~h}$ for $24 \mathrm{~h}$ and $4 \mathrm{mg} / \mathrm{kg}$ at $12 \mathrm{~h}$ interval [26], suggesting that pharmacokinetics links efficacy and safety, thereby assist in determination of dosage regimen in clinical practice [99]. Elimination process of two compartment models is by Michaelis-Menten kinetics [100]. In one substrateone product reversible enzyme reaction, the rapid equilibrium in one direction eliminates rapid equilibrium in the reverse direction. Van Slyke type kinetic constant appears in the rate equation independent of whether steady state, finite time or final equilibrium is attained. Also the reaction could proceed in one direction with fast equilibrium and in the opposite direction with steadystate kinetics. Hence the thermodynamic equilibrium determines that a higher concentration of product or substrate could be reached only with steady-state kinetics [101]. A low Michaelis constant $(\mathrm{Km})$ corresponds to a high binding capacity between enzymes and substrates [102], suggesting that tylosin, puromycin and vorioconazole bind strongly to their receptors as compared to other drugs being studied. In both typical and atypical (non-hyperbolic) parameters, in vitro kinetic parameters are scaled for prediction of in vivo metabolic clearance for dose projection [73].

\section{Limitations of in vitro-in vivo kinetic translation for optimization of pharmacokinetic/Pharmacodynamic parameters}

In vitro-in vivo kinetic translation is useful in drug research and development. However pharmacokinetic parameters such as ADME could be affected at various levels of drug disposition. Phenytoin is postulated to have a limited window of absorption via carriermediated mechanism [103]. There was a significant correlation between steady-state serum levels of phenytoin calculated from Vmax and Km values in epileptics. Single doses were initially administered followed by multiple doses [36]. Hence phenytoin could have zero order input and mixed order kinetic ouput in one compartmental model system [104], suggesting that level of plasma phenytoin is not related linearly to dose and change in enzyme activity by co-administered drug, could alter plasma level of phenytoin. What a serious therapeutic setback! More so $\mathrm{Km}(0.8 \mu \mathrm{mol} / \mathrm{L})$ and Vmax $(1.3 \mu \mathrm{mol} / \mathrm{h})$ have been reported for phenytoin coadministered with diazepam. The values rose to $50.3 \mu \mathrm{mol} / \mathrm{L}$ and $4.4 \mu \mathrm{mol} / \mathrm{L} / \mathrm{h}$ after diazepam elimination [93]. So single intravenous dose, multiple dose and constant dose injection of one compartment models could obey mixed order (Michaelis-Menten) kinetics [55], suggesting that nonlinearity could be observed in drug ADME, which varies from drug to drug, according to route of administration, dosage formulation and diseased conditions [4]. This shows that there is need to establish a dose range with a reasonable relationship between plasma AUC and dosage during subchronic and chronic toxicity studies [105]. The scaling of Vmax and $\mathrm{Km}$ gives in vivo metabolic clearance as proven by Vmax/Km ratio [106]. However, many drugs show atypical Michaelis-Menten kinetics that are sigmoidal, biphasic, substrate inhibitory and heterotropic [45], making prediction of in vivo parameters from in vitro data sometimes not exact, and as such should not be based on a single set of data [107]. This is linked to pharmacokinetic/pharmacodynamic modeling that targets drug concentration and effect [108]. Incorrect 
application of Michaelis-Menten model can result in underestimation of $\mathrm{Km}$ and Vmax, but its application to sigmoidal kinetic data could result in overestimation of $\mathrm{Km}$ and Vmax at lower concentration of substrate [55], with good correlation between in vitro drug release and in vivo drug absorption, leading to optimized Cmax, Tmax and AUC [109]. Therefore, therapeutic concentration and diagnosis of clinical toxicity of drugs in question, patient compliance and dosage adjustments are clinically useful, especially for patients with greater pharmacokinetic variability [110]. Hence significantly decreased $\mathrm{Km}$ than Vmax could result in increased clearance [13], suggesting that linear kinetics removes the regulatory ligand faster, whereas non-linear kinetics delays the removal of regulatory ligand [111]. In spite of the fact that Henri derived equation for enzyme reaction in 1903 [112], significant progress was made by Michelis-Menten in this regard about 100 years ago [113], with many modifications, including the derivation of complex kinetics, where first and second reactions were fast. All these were achieved within the past century [114-118] suggesting that a typical kinetics could be biphasic, homotropic and heterotropic [119]. Hence, some statistical assumptions used in analysis of enzyme kinetic data maybe implicit $[120,121]$. Therefore this paper has integrated both in vitro and in vivo equations for identification of enzyme inducing and inhibiting drugs, as well as xenobiotics that undergo enzymatic reactions above Michaelis-Menten order. So what a nice progress made in the area of enzyme kinetics for the past 57 years!

\section{Conclusion}

Many drugs undergoing pharmacokinetics, either obey Michaelis-Menten order (first order, zero order and mixed order) or order above Michaelis-Menten Kinetics. However, the concentrations of drugs and enzymes involved, determine the order of kinetics. More so, in vitro kinetics could be integrated with in vivo MichaelisMenten kinetics for optimization of pharmacokinetic/ pharmacodynamic translation in order to achieve clinical efficacy and safety. Mixed order kinetic drugs are either enzyme inducers or inhibitors.

\footnotetext{
Abbreviations

$V_{0}$ : Initial velocity; $V_{\text {max }}$ : Maximum velocity; $C s$ : Concentration of substrate; Ko: Initial metabolism constant; Co: Initial concentration of substrate; Cl: Clearance; DR: Dose rate; Css: Steady-state concentration; S: Substrate; R: Rate of endogenous substrate production; Clint: Intrinsic clearance; Clu: Urinary excretion; Vd: Volume of distribution; LD: Loading dose; Ki: Inhibition constant; $I_{50}$ : Inhibitory concentration fifty; $I_{\max }$ : Maximal inhibitory concentration; Ip: Inhibitory potential; Pm: Carrier-mediated

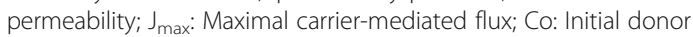
concentration of the substance; MR: Metabolic rate; a: Allometric constant for all mammals; M: Body mass; CMR: Cellular metabolic rate; ds: Change of substrate; dt: Change of time; $\mu$ : Kinetic mean; $\vee$ : Volume of drug: Kcat: Catabolism constant; $\mathrm{E}_{\mathrm{T}}$ : Total enzyme concentration; Es: Enzyme
}

substrate; Kinfus: Infusion constant; ES ss: Steady-state-enzyme substrate; A: Lower boundary for concentration; B: Maximum concentration; K: Constant; KE: Elimination constant; KA: Absorption constant; $D_{1}$ : First dose; $D_{2}$ : Second dose; $D_{3}$ : Third dose; $\beta$ : Elimination rate constant; MRT: Mean residence time; AUC: Area under curve; AUMC: Area under moment curve; $\mathrm{T} 1 \frac{2}{2} \beta$ : Terminal half = life; Pcl: Plasma clearance; $V \mathrm{C}$ : Volume of central compartment; $K_{10}$ : Rate constant of elimination; $V_{a p p}$ : Apparent volume of distribution; Vss: Steady-state volume of distribution; iv: Intravenous; PK: Pharmacokinetics; QT: Depolarization-repolarization of the heart ventricle; CYP: Cytochrome P450; NAD: Nicotinamide adenine dinucleotide; Km: Metabolism constant maximum; DNA: Deoxyribonucleic acid;3-MX: 3methylxanthine; 1,3-DMU:1,3 dimethyluric acid;1-MU:1-methyluric acid

\section{Acknowledgements}

I sincerely thank Moses Adojutelegan Ojo of the Department of Science Education, Federal University of Agriculture Makurdi for typing the work.

\section{Author's contributions}

SAS conceived the idea, designed and carried out the study, analyzed the data, wrote proofread and approved the manuscript.

\section{Funding}

The study was carried out using my monthly emoluments. The funding bodies played no role in the design of the study and collection, analysis, and interpretation of data, and in writing the manuscript.

\section{Availability of data and materials}

The data generated are included in the manuscript.

\section{Declarations}

Ethics approval and consent to participate Not applicable.

\section{Consent for publication \\ Not applicable.}

\section{Competing interests}

Not applicable.

Received: 14 September 2020 Accepted: 6 September 2021 Published online: 11 October 2021

\section{References}

1. Saganuwan SA. Unique pharmacokinetic and pharmacodynamic parameters of antinicrobals in goats. In: Goat, Intech Open: London; 2019. p. 1-24.

2. Satori CP, Henderson MM, Krautkramer EA, Kostal V, Distefano MM, Arriaga FA. Bioanalysis of eukaryotic organelles. Chem Rev. 2013;113(4):2733-311. https://doi.org/10.1021/cr300354g.

3. Metzler CM, Tong DDM. Computational problems of compartment models with Michaelis-Menten-type elimination. Pharmaceutic Sci. 1981;7013:733-7.

4. Wagner JG. Properties of the Michaelis - Menteneqution and its integrated firm which are useful in pharmacokinetics. J Pharmacokinet Biopharmaceut. 1973;1(2):103-21.

5. Gunaratna C. Drug metabolism and pharmacokinetics in drug discovery: a primer for bioanalytical chemistry, part II. Curr Separat. 2001;19(3):87-92.

6. Amsden JR, Gubbins PO, McConnell S, Anaissie E. Steady-state pharmacokinetics of oral voriconazole and its primary metabolite, $\mathrm{N}$-oxide voriconazole pre- and post-autologous peripheral stem cell transplantation. AAC. 2013;57(7):3420-3. https://doi.org/10.1128/AAC.00046-13.

7. Argikar UA, Cloyd JC, Birnbaum AK, Leppik IE, Conway J, Kshirsagar S, et al. Paradoxical urinary phenytoin metabolite $(S) /(R)$ ratio in CYP2C19 1/2 patients. Epilepsy Res. 2006;71(1):54-63. https://doi.org/10.1016/j. eplepsyres.2006.05.015

8. Conney AH, Gilman AG. Puromycin Inhibition of enzymes induction by 3methylcholanthrene and phenobarbital. J BiolChem. 1963;238:3682-5.

9. Choi B, Rempala GA, Kim JK. Beyond the Michaelis-Menten equation: accurate efficient estimation of enzyme kinetic parameters. Sci Report. 2017; 17(1):1-11. https://doi.org/10.1038/s41598-017-17072-z.

10. Cordato DJ, Mather LE, Gross AS, Herkes GK. Pharmacokinetics of thiopental enantiomers during and following prolonged high- dose therapy. 
Anesthesiol. 1999;91(6):1693-702. https://doi.org/10.1097/00000542-199912 000-00022.

11. Covey JM, Straw JA. Nonlinear pharmacokinetics of thymidine, thymine, and fluorouracil and their kinetic interactions in normal dogs. Cancer Res. 1983; 43(10):4587-95.

12. De Verdier $\mathrm{CH}$, Potter VR. Alternative pathway of thymine and uracil metabolism in the liver and hepatoma. J Natl Cancer Inst. 1970;24(1):13-29.

13. Fukuchi Y, Toshimoto K, Mori T, Kakimoto K, Tobe Y, Sawada T, et al. Analysis of nonlinear pharmacokinetics of a highly albumin-bound compound: contribution of albumin-mediated hepatic up take. J Pharm Sci. 2017;106(9):270-2714. https://doi.org/10.1016/j.xphs.2017.04.052.

14. Fischer $E$, Gregus Z, Varga F. Effects of barbiturates on the hepatic cytochrome P-450 dependent enzyme system and biliary excretion of exogenous organic anions in rats. Digestion. 2012;1980(2):115-20. https:// doi.org/10.1159/000198428

15. Godwin C. Effects of puromycin on the metabolism of phenylalanine in rats. Canad J Biochem. 1967;45(12):1961-4. https://doi.org/10.1139/067-229.

16. Grandvuinet AS, Vestergaard HT, Rapin N, Steffensen B. Intestinal transporters for endogenic and pharmaceutical organic anions: the challenges of deriving in -vitro kinetic parameters for the prediction of clinically relevant drug-drug interactions. J Pharm Pharmacol. 2012;64(11): 1523-48. https://doi.org/10.1111/j.2042-7158.2012.01505.x.

17. Gumes A, Coskum U, Boruban C, Gumel N, Babaoglu NO, Sencan O, et al. Inhibitory effect of 5 -fluoororacil on cytochrome P450 2C9 activity in cancer patients. Basic ClinPharmacolToxicol. 2006;98:197-200.

18. Heggie GD, Sommadossi JP, Diassio RB. Clinical pharmacokinetics of 5 fluorouracil and its metabolites in plasma, urine and bile. Cancer Res. 1987; 47(8):2203-6.

19. Hull WE, Port RE, Herrmann R, Britsch B, Kunz W. Metabolites of 5fluorouracil in plasma and urine as monitored by ${ }^{19} \mathrm{~F}$ nuclear magnetic resonance spectroscopy, for patients receiving chemotherapy with or without methotrexate pretreatment. Cancer Res. 1988:48(6):1680-8.

20. Kmetec $E$, Tirpack A. Metabolism of puromycin aminonucleoside in the rat: formation of nucleotide derivatives. BiochemPharmacol. 1970;19(4):1493-500

21. Kolz AC, Moorman TB, OngSK SKD, Douglass EA. Degradation and metabolite production of tylosin in anaerobic and aerobic swine-manure lagoons. Water Envir Res. 2005;77(1):49-56. https://doi.org/10.2175/106143 $005 \times 41618$.

22. Kosmidis K, Karalis V, Argyrakis P, Macheks P. Michaelis -Menten kinetics under spatially constrained conditions: application to mibefradil pharmacokinetics. Biophys J. 2004;87(3):1498-506. https://doi.org/10.1529/ biophysj.104.042143.

23. Kudo T, Endo Y, Taguchi R, Yatsu M, Ito K. Metronidazole reduces the expression of cytochrome P450 enzymes in HepaRG cells and cryopreserved human hepatocytes. Xenobiotic. 2015;45(5):413-9. https://doi.org/10.3109/ 00498254.2014.990948

24. Lesko LJ. Dose - dependent kinetics of theophylline. J Allergy Clinlmmunol. 1986;78(4,2):723-7

25. Lissner R, Merk H, Bolsen K, Goerz G. Interaction between theophylline and drug metabolizing. Liver enzymes in the rat. Arzneimittelfors. 1988;35(12): 1825-7

26. Liu P, Nould DR. Population pharmacokinetic analysis of vorionazole and anidulfuntin in all adult patients with invasive aspergillosis. Antimicrob Agents Chemother. 2014;58(5):47.

27. Mahaptra S, Woolhise LK, Lenaerts AJ, Johnson JL, Eisenach KD, Joloba ML, et al. A novel metabolite of antituberculosis therapy demonstrate host activation of isoniazid and formation of the isoniazid-NAD+adduct. AAC. 2012;56(1):28-33.

28. Meinertz T. Mibefradil-a drug which may enhance the propensity for the development of abnormal QT prolongation. Eur Heart J. 2001;3:89-92. https://doi.org/10.1016/S1520-765X(01)90011-2.

29. Miura K, Kinouchi M, Ishida K, Fujibuchi W, Naitoh T, Ogawa H, et al. 5-FU metabolism in cancer and orally-administrable 5-FU drugs. Cancer. 2010;2(3): 1717-30. https://doi.org/10.3390/cancers2031717.

30. Moriyama B, Elinoff J, Danner RL, Gea-Banachoche J, Pennick G, Rinaldi MG, et al. Accelerated metabolism of voriconazole and its partial reversal by cimetidine. AAC. 2009;53(4):171-1714. https://doi.org/10.1128/AAC.01221-08.

31. Mullins ME, Horowitz BZ, Linden DHJ, Smith GW, Norton RL, Stump J. Lifethreatening interaction of mibefradil and $\beta$-blockers with dihydropyridine calcium channel blockers. JAMA. 1998;280(2):157-8. https://doi.org/10.1001/ jama.280.2.157.
32. Muti C, Shoji S, Tomono Y, Liu P. Population pharmacokinetic analysis of voriconazole from a pharmacokinetic study in immunocompromized Japanese paediatric subjects. Antimicrob Agents Chemother. 2015. https:// doi.org/10.1128/AAC.04993-14.

33. Nguyen KT, Stephens DP, Mcleish MU, Crankshaw DP, Morgan DJ. Pharmacokinetics of thiopental and pentobarbital enantiomers after intravenous administration. AnesthAnalg. 1996;83(3):552-8.

34. Nivoix Y, Babul S, Engel P, Ceveque D, Herbrecht R, Ubeaud G. Inhibition effects of four antifungal triazoles (itraconazole, Fluconazole, Voriconazole and Posaconazole) on specific activities of CYP3A4 in human liver microsomes. 19 ${ }^{\text {th }}$ Eur. CongrClinMicrobiollnfect Dis 2009.

35. Peters $\mathrm{JH}$, Miller KS, Brown P. The determination of isoniazid and its metabolites in human urine. AnalytBiochem. 1965;12(2):379-94. https://doi. org/10.1016/0003-2697(65)90105-3

36. Popvic KJ, Posa M, Popovic DJ, Laloberic D, Popovic JK. Validation of individual non-linear predictive pharmacokinetic parameters in a rabbit phenyloin model. Trop J Pharmaceut Res. 2014;13(8):1295-302. https://doi. org/10.4314/tjpr.v13i8.14

37. Rogers HJ, Haslam RA, Longstreth J, Lietman PS. Phenytoin intoxication during concurrent diazepam therapy. J NeurosurgPsychiat. 1977;40(9):890-5. https://doi.org/10.1136/jnnp.40.9.890

38. Spriet I, Meersseman P, Meersseman W, de Hoon J. Increasing the dose of voriconazole compensates for enzymes induction by phenytoin. $\mathrm{Br} J \mathrm{Clin}$ Pharmacol. 2010;69(6):701-2. https://doi.org/10.1111/j.1365-2125.2010.03650.x.

39. Scholtz I, Oberwittler H, Riedel KD, Burhenne J, Weiss J, Haefell WE, et al. Pharmacokinetics, metabolism and bioavailability of the triazole antifungal agent, voriconazole in relation to CYP2C19 genotype. Br J Pharmacol. 2009; 68(6):906-15.

40. Siethoff C, Orth M, Ortling A, Brendel E, Wagner-Redeker W. Simultaneous determination capacitabine and its metabolite 5 -fluorouracil by column switching and liquid chromatography/tandem spectrometry. J Mass Spectr. 2004:39(8):884-9.

41. Spinazzola A, Marti R, Nishino I, Andreu AL, Naini A, Tadesse S, et al. Altered thymidine metabolism due to defects of thymidine phosphorylase. J BiolChem. 2002;277(6):4128-33. https://doi.org/10.1074/jbc.M111028200.

42. Theuretzbacher U, Ihle F. DerendorfH.Pharmacokinetic/pharmacodynamics profile of voriconazole. ClinPharmacokinet. 2006;45(7):649-63. https://doi. org/10.2165/00003088-200645070-00002.

43. Thorn CF, Whirl-Carrillo M, Leeder JS, Klein TE, Altman RB. Pharm GKB: Phenytoin pathway. Pharmacogenet Genomic. 2012;22(6):466-70. https:// doi.org/10.1097/FPC.0b013e32834aeedb.

44. Timbrell JA, Wright JM, Smith CM. Determination of hydrazine metabolites of isoniazid in human urine by gas chromatography. J Chromatogr. 1977; 38(1):165-72. https://doi.org/10.1016/S0021-9673(00)98007-5.

45. Tracy TS, Hummel MA. Modeling kinetic data from in vitro drug metabolism enzyme experiments. Drug Metab Rev. 2004;36(2):231-42. https://doi.org/1 0.1081/DMR-120033999.

46. van Gennip AH, Abeling NG, Elzinga-Zoetekouw L, Scholten LG, van Cruchten A, Bakker HD. Comparative study of thymine and uracil metabolism in healthy persons and in a patient with dihydropyrimidine dehydrogenase deficiency. Adv Exp Med Biol. 1989;253A:111-8. https://doi. org/10.1007/978-1-4684-5673-8_17

47. Wandel C, Kim RB, Guengerich FP, Wood AJJ. Mibefradil is a P-glycoprotein substrate and a potent inhibitor of both P-glycoprotein and CYP3A in vitro. Drug MetabDispos. 2000:28(8):895-8.

48. Witherspoon M, Chen Q, Kopelovich L, Gross SS, Lipkin SM. Unbiased metabolite profiling indicates that a diminished thymidine pool is the underlying mechanism of colon cancer chemoprevention by alphadifluoromethylornithine. Cancer Discov. 2013;3(9):1072-81. https://doi.org/1 0.1158/2159-8290.CD-12-0305.

49. Witmer DR, Ritschel WA. Phenytoin- isoniazid interaction: a kinetic approach to management. Drug IntellingClin Pharm. 1984;18(6):483-6. https://doi. org/10.1177/106002808401800607.

50. Zhang N, Yin Y, Xu S-J. Chen W-S.5-flouroracil mechanisms of resistance and reversal strategies. Molecules. 2008;13(8):1551-69. https://doi.org/10.3390/ molecules13081551.

51. Zonios D, Yamazaki H, Murayama N, Bennett JE. Voriconazole metabolism, toxicity, and the effect of cytochrome P4502C19 genotype. JID. 2014 209(12):1941-8. https://doi.org/10.1093/infdis/jiu017.

52. Ahluwalia A. Allometric scaling in vitro. Sci Rep. 2017:7(1):1-7. https://doi. org/10.1038/srep42113. 
53. Markov S. Cell growth models using reaction schemes: batch cultivation. Biomath. 2013;2(2):1-9.

54. Ramsay RR, Tipton KF. Assessment of enzyme inhibition:a review with examples from the development of monoamine oxidase and cholinesterase inhibitory drugs. Molecules. 2017;22(7):1192. https://doi.org/10.3390/ molecules22071192.

55. Tang S, Xiao Y. One compartment model with Michaelis-Menten elimination kinetics and therapeutic window: an analytic approach. J Pharmacokinet Pharmacodyn. 2007;34(6):807-27. https://doi.org/10.1007/s10928-007-9070-4.

56. Daniel WD. Biostatistics: Basic Concepts and Methodology for the Health Sciences, vol. 783. 9th edit ed. UK: Wiley; 2013.

57. Wu S, Zhang M, Vest PA, Bhttacharjee A, Liu L, Li M. A mibefradil metabolite is a potent intercellular blocker of $\mathrm{L}$-type $\mathrm{Ca}^{+}$currents in pancreatic $\beta$-cells. $J$ Pharmacol Exp Ther. 2000;292:939-43.

58. Popovic J. Classical Michaelis-Menten and system theory approach to modeling metabolite formation kinetics. Eur J Drug Metab Pharmackinet. 2004;29:2005-14.

59. Stem AM. Practical unidentifiability of receptor density in target mediated drug disposition concentration data; 2017. p. 1-14. https://doi.org/10.11 01/123240.

60. Segel IH. Rapid equilibrium bireactant and terreactant systems. New York: Wiley; 1975.

61. Wiltshire HR, Sutton BM, Heeps G, Betty AM, Angus DW, Harris SR Metabolism of the calcium antagonist, mibefradil part III. Comparative pharmacokinetics of mibefradil and its major metabolites in , marmoset and cynomolgus monkey. Xenobiotica. 2008;27(6):557-71. https://doi.org/10.1 080/004982597240343.

62. Sandherr M, Maschmeyer G. Pharmacology and metabolism of voriconazole and posaconazole in the treatment of invasive aspergillosis-review of the literature. Eur J Med Res. 2011;16(4):139-44. https://doi.org/10.1186/2047783X-16-4-139.

63. Toutain PL, Bousquet-Melou A. Plasma terminal halflife. J Vet PharmacolTher. 2004;27:427-39.

64. Ellard GA, Gammon PT. Pharmacokinetics of isoniazid metabolism in man. J Pharmacokinet Biopharmaceut. 1976;4(2):83-113. https://doi.org/10.1007/ BF01086149.

65. Peretti E, Karlaganis $G$, Lauterburg BH. Increased urinary excretion of toxic hydrazine metabolites by slow acetylators. Effect of a slow-release preparation of isoniazid. Eur J ClinPharmacol. 1987;33:283-6.

66. Shimokawa Y, Yoda N, Kondo S, Yamamura Y, Takiguchi Y, Umehara K Inhibitity potential of twenty-five anti-tuberculosis drugs on CYP activities in human liver microsomes. Boil Pharm Bull. 2015;38(9):1425-9. https://doi. org/10.1248/bpb.b15-00313.

67. Mehvar R. Principles of nonlinear pharmacokinetics. AJPE. 2001;65:178-84.

68. Pearce RE, Cohen-Wolkowiez M, Sampson MR, Kearns GL. The role of human cytochrome 1450 enzymes in the formation of 2 - hydroxyl metronidazole: CYP2A6 is the high affinity (low km) catalyst. Drug MetabDispos. 2013;41:1686-94

69. Yamaoka K, Takakura Y. Analysis methods and recent advances in nonlinear pharmacokinetics from in vitro through in loci to in vivo. Drug Metab Pharmacokinet. 2004;19(6):397-406. https://doi.org/10.2133/ dmpk.19.397.

70. Di Cera E, Hopfner KP, Dang QD. Theory of allostetic effects in serine proteases. Biophys J. 1996;70(1):174-81. https://doi.org/10.1016/S0006-34 95(96)79558-9

71. Subramanian M, Tracy TS. Methods for determination of enzyme kinetics and metabolic rates. Encyclopedia of Drug Metabolism and Interactions, 2012.

72. Sharma KR. On single compartment pharmacokinetic model systems that obey Krebs cycle kinetics. J EncapsAdsorpSci. 2011;1:43-50.

73. Zheng F, Zhan CG. Modeling of pharmacokinetics of cocaine in human reveals the feasibility for development of enzyme therapies for drugs of abuse. PLoS Comput Biol. 2012;8(7):1-10. https://doi.org/10.1371/journal. pcbi.1002610

74. Martins AM. Inborn errors of metabolism: a clinical review. Sao Paulo Med J. 1999;117(6):251-65.

75. Toulias PL, Kitsos CP. Estimation aspects of the Michaelis-Menten model. Revstat Statist J. 2016;14(2):101-18.

76. Herenda S, Ostijic J, Haskovic E, Haskovic D, Milos M, Galic B. Electrochemical investigation of the influx of $k_{2}\left(\mathrm{~B}_{3} \mathrm{O}_{3} \mathrm{~F}_{4} \mathrm{OH}\right)$ on the activity of immobilized superoxide dismutase. In J Electrochem Sci. 2018;13:3279-87.
77. Koshkin V, Krylov SN. Correlation between multi-drug resistance associated membrane transport in clonal cancer cells and the cell cycle phase. PLoS One. 2012;7(7):1-8. https://doi.org/10.1371/journal.pone.0041368.

78. Piel MT, Alclrete JA, Jones $\mathrm{G}$. Influence of enzymes induction on the sleeping time of rats. Can Anaes Soc J. 1979;16(6):538-46. https://doi.org/1 0.1007/BF03004547.

79. Kim RB. Drugs as p-glycoprotein susbstrate inhibitors and inducers. Drug Metab Rev. 2002;34(1-2):47-54. https://doi.org/10.1081/DMR-120001389.

80. Synoid TN, Dussault I, Forman BN. The orphan nuclear receptor SXR coordinatively regulates drug metabolism and efflux. Nat Med. 2001;7(5): 584-90. https://doi.org/10.1038/87912.

81. Perucca E. Clinically relevant drug interactions with antiepileptic drugs. Br Clin Pharmacol. 2005;61(3):246-55. https://doi.org/10.1111/j.1365-2125.2005. 02529.x.

82. Brodie MJ, Mintzer S, Pack AN, Gidal BE, Vecht CJ, Schmidt D. Enzyme induction with antiepileptic drugs: cause for concern. Epilepsia. 2013;54(1): 11-27. https://doi.org/10.1111/j.1528-1167.2012.03671.x.

83. Cannon M. The puromycin reaction and its inhibition by chloramphenicol. European J Biochem. 1968;7(1):137-45. https://doi.org/10.1111/j.1432-1033.1 968.tb19584.x

84. Wen X, Wang JS, Neuvonen PJ, Backman JT. Isoniazid is a mechanism based inhibitor of cytochrome P4501A2, 2A6, 2C19 and 3A4 isoforms in human liver microsomes. Eur J Clin Pharmacol. 2002;57(11):799-804. https://doi. org/10.1007/s00228-001-0396-3

85. Lynch T, Price A. The effect of cytochrome P450 metabolism on drug response, interactions and adverse effects. Am Fam Physician. 2007;76:391-6.

86. Veronese ML, Gillen LP, Dorval EP, Hauck WW, Waldman SA, Greenberg HE. Effect of mibefradil on CYP3A4 in vivo. Clin Pharmacol Ther. 1999;65(2):131.

87. Sweeney BP, Bromillow J. Liver enzymes induction and inhibition. Anaesthesia. 2006;61 (2):159-77. https://doi.org/10.1111/j.1365-2044.2005.044 62.x.

88. Maronpot RR, Yoshigawa K, Nyska A, Harada T, Flake G, Mueller G, et al. Hepatic enzymes induction: histopathology. ToxicolPathol. 2010;38(5):77695. https://doi.org/10.1177/0192623310373778.

89. JLE M, Montes MR, Rossi RC. Steady - state analysis of enzymes with non Michaelis - Menten equation kinetics the transport mechanism of $\mathrm{Na}^{+} / \mathrm{K}^{+}$ATPase. J Biol Chem. 2018;293(4):1373-85.

90. Rogers Z, Hiruy H, Pasipanodya JG, Mbowane C, Adamson J, Ngotho L, et al. The non-linear child: ontogeny, isoniazed concentration, and NATs phenotype modulate enzyme reaction kinetis and metabolism. EBioned. 2016;11:118-26. https://doi.org/10.1016/j.ebiom.2016.07.031.

91. Robinson PK. Enzymes: principles and biotechnological applications. Essays Biochem. 2015;59:1-41. https://doi.org/10.1042/bse0590001.

92. Cho $\mathrm{S}$, Yoon TR. Understanding the pharmacokinetics of reversible metabolism. Transl Clin Pharmacil. 2019;27(2):52-8. https://doi.org/10.12793/ tcp.2019.27.2.52.

93. Dubois A, Gsteiger S, Balser S, Pigeolet E, Steoma JL, Pillai U, et al. Pharmacokineti similarity of biologics: analysis using nonlinear mixed-effects modeling. Clin Pharmacol Ther. 2020:1-12.

94. Benet LZ. Zia- Amir hosseini P. basic principles of pharmacokinetics. Toxicolpathol. 1995;23(2):115-23. https://doi.org/10.1177/019262339502300203.

95. Gabrielsson J, Peletier LA. Michaelis -Menten from an in vivo perspective: open versus closed systems. AAPS J. 2018;20(102):1-13. https://doi.org/10.12 08/s12248-018-0256-z

96. Tomaczak JN, Weglarz-Tomaczak E. Estimating kinetic constants in the Michaelis- Menten model from one enzymatic assay using approximate Bayesian computation. FEBS Lett. 2019;593(19):274-2750. https://doi.org/10.1 002/1873-3468.13531.

97. Rodrigues LVS, Breda A, Santis DS, Basso LA. The conserved lysine 69 residue plays a catalytic role in Mycobacternim tuberculosis shikimate dehydrogenase. BNC Res Note. 2009;2(227):1-7.

98. Gilibili RR, Chatterjee S, Bagul P, Mosure KW, Nurali BV, Mariappan TT, et al Coproporphyning: a fluorescent, endogenous optimal probe substrate for ABCC 2 (MRP 2 ) suitable for vesicle-based MRP inhibition assay. Drug Metab Dispos. 2017:45:604-11.

99. Dunnington K, Benrimoh N, Brandquist C, Cardillo-Marrico N, Di Spirit M, Grenier J. Application of pharmacokinetics in early drug development. Intech open. 2018:57-75. https://doi.org/10.5772/intechopen.74189.

100. Bertrand J, Mentre D. Mathematical expressions of the pharmacokinetics and pharmacodynamics models implemented in the monolix software. Paris Diderot University. 2008:1-68. 
101. Keleti T. Two rules of enzyme kinetics for reversible Michaelis-Menten mechanisms. FEBS Let. 1986;208(1):109-12. https://doi.org/10.1016/00145793(86)81542-3.

102. Daintith J. A dictionary of chemistry. 6th ed. Oxford: Oxford University press; 2008. p. 584. https://doi.org/10.1093/acref/9780199234004.001.0001.

103. Wood JH, Thakker KM. Michaelis- Menten absorption kinetics in drugsexamples are implicatons. Eur J ClinPharmacol. 1982;23:183-8.

104. Lam G, Chiou WL. Integrated equation to evaluate accumulation profiles of drugs eliminated by Michaelis- Menten kinetics. J Pharmacokinet Biopharmaceut. 1979;7(2):227-32. https://doi.org/10.1007/BF01059740.

105. Lin JH. Dose-dependent pharmacokinetics: experimental observations and theoretical considerations. Biopharmaceut Drug Dispos. 1994;15:1-31.

106. Houston JB. Relevance of in vitro kinetic parameters to in vivo metabolism of xenobiotics. Toxicol in Vitro. 1994;8(4):509-12. https://doi.org/10.1016/ 0887-2333(94)90002-7.

107. Wilkinson GR. Prediction of in vivo parameters of drug metabolism and absorption from in vitro studies. Pharmacokinetic Risk Assessment: Drinking Water. 1987;8:1-507.

108. Tonge PJ. Drug-target kinetics in drug discovery. ACS ChemNeurosci. 2018; 9(1):29-39. https://doi.org/10.1021/acschemneuro.7b00185.

109. Shah KU, Khan GM. Regulating drug release behavior and kinetics from matrix tablets based on fine particle-sized ethyl cellulose ether derivatives: an in vitro and in vivo evaluation. ScientificWorldJournal. 2012;2012:842348.

110. Wu MF, Lim WH. Phenytoin: a guide to therapeutic drug monitoring. Proc Singapore Health Care. 2013;22(3):198-202. https://doi.org/10.1177/20101 0581302200307.

111. Goldbeter A. Oscillatory enzyme reactions and Michaelis-Menten kinetics. FEBS Lett. 2013;587(17):2773-84. https://doi.org/10.1016/.febslet.2013.07.031.

112. Segel IH. Enzyme kinetics : behaviour and analysis of rapid equilibrium and steady-state enzyme systems. New York: A Wiley-Interscience Publications, John Wiley \& Sons; 1975. p. 1-97.

113. Cornish-Bowden A. One hundred years of Michaerlis-Menten kinetics. Perspect Sci. 2015;4:3-9. https://doi.org/10.1016/j.pisc.2014.12.002.

114. Prats M, Forestier JP. A new approach to Michaelis-Menten kinetics and enzyme inhibition. Biochem Educ. 1988;16(4):217-21. https://doi.org/10.101 6/0307-4412(88)90126-4.

115. Roskoki R. Michaelis-Menten kinetics. Ref Module Biomed Res. 2015. https:// doi.org/10.1016/B978-02-8.01238-3.05143-6.

116. Kim JK, Tyson JJ. Misuse of the Michaelis-Menten rate law for protein interaction networks and its remedy. PLoS Comput Biol. 2020;16(10):1-21.

117. Wagner JG. Properties of the Michaelis-Menten equation and its integrated form which are useful in pharmacokinetics. J Pharmacokinet Biopharmaceut. 1973;1(2):103-21. https://doi.org/10.1007/BF01059625.

118. Monti JLE, Montes MR, Rossi RC. Steady-state analysis of enzymes with nonMichaelis-Menten kinetics in the transport mechanism of $\mathrm{Na}+/ \mathrm{K}+\mathrm{AT}$ pase. J Biol Chem. 2018;293(4):1373-85. https://doi.org/10.1074/jbc.M117.799536.

119. Leow JWH, Chan ECY. Atypical Michaelis-Menten kinetics in cytochrome P450 enzymes: a focus on substrate inhibition. Biochem Pharmacol. 2019; 169:1-9. https://doi.org/10.1016/.j.bcp.2019.08.017.

120. Cornish-Bowden A. Analysis and interpretation of enzyme kinetic data. Perspect Sci. 2014;1:121.

121. Patsatzis DG, Goussis DA. A new Michaelis-Menten equation valid everywhere multi-scale dynamics prevails. Math Biosci. 2019;315:1-13. https://doi.org/10.1016/j.mbs.2019.108220.

\section{Publisher's Note}

Springer Nature remains neutral with regard to jurisdictional claims in published maps and institutional affiliations.

Ready to submit your research? Choose BMC and benefit from:
- fast, convenient online submission
- thorough peer review by experienced researchers in your field
- rapid publication on acceptance
- support for research data, including large and complex data types
- gold Open Access which fosters wider collaboration and increased citations
- maximum visibility for your research: over 100M website views per year
At BMC, research is always in progress.
Learn more biomedcentral.com/submissions

